\title{
Associations between Physical Activity, Depression, and Quality of Life in Elderly: Meta-Analysis
}

\author{
Fatchurrohmah Ines Prabandari'), Bhisma Murti'), Hanung Prasetya ${ }^{2)}$ \\ ${ }^{1)}$ Masters Program in Public Health, Universitas Sebelas Maret \\ ${ }^{2)}$ Study Program of Accupuncture, Health Polytechnics, Ministry of Health Surakarta
}

\section{ABSTRACT}

Background: The aging process is associated with a greater prevalence of long-term health problems. One of them is a significant increase in problems including mental health problems in the elderly demographic. The World Health Organization (WHO) estimates that about one in every ten elderly people suffer from depression, which is a factor that can reduce the quality of life (QOL) of the elderly. QOL can be conceptualized as a set of harmonious satisfactions that individuals get in their daily lives by taking into account the physical, psychological and social aspects of life. Good QOL for the elderly can be interpreted as feeling better in carrying out basic daily activities (Activity of Daily Living/ ADLs) properly and living independently. One of the aspects that play an important role in improving the quality of life of the elderly is physical activity. This study aims to determine the average strength of the relationship between physical activity and depression and quality of life in the elderly based on the results of previous research.

Subjects and Method: This study is a systematic review and meta-analysis using a crosssectional design. The articles used in this study were obtained from several databases including PubMed, Google Scholar, Springerlink, and Sciencedirect. The articles used in this study are those published from 2010-2020. The article search was carried out by considering the eligibility criteria defined using the PICO model. P: Male and female aged $\geq 60$ years, I: Physical activity, C: sedentary behavior $\mathrm{O}$ : Depression and Quality of Life. The keywords to search for articles were as follows: "physical activity", "depression", "quality of life", "elderly", "cross-sectional" and "adjusted odds ratio". The articles included in this study are full text articles with a cross-sectional study design. Articles were collected using PRISMA flow diagrams and analyzed using the Review Manager 5.3 application.

Results: A total of 16 articles were reviewed in this study. The meta-analysis showed that physical activity can reduce the risk of depression in the elderly $(\mathrm{aOR}=0.72 ; 95 \% \mathrm{CI}=0.52$ to 1.00; $\mathrm{p}<0.001)$. The meta-analysis also showed that physical activity can improve the quality of life of the elderly $(\mathrm{aOR}=1.25 ; 95 \% \mathrm{CI}=1.05$ to 1.48; $\mathrm{p}<0.001$ ).

Conclusion: Physical activity can reduce the risk of depression and can improve the quality of life among elderly.

Keywords: physical activity, depression, quality of life, elderly, cross-sectional

\section{Correspondence:}

Fatchurrohmah Ines Prabandari. Masters Program in Public Health, Universitas Sebelas Maret. Jl. Ir. Sutami 36A, Surakarta 57126, Central Java. Email: inesfatchur@gmail.com.

Cite this as:

Prabandari FI, Murti B, Prasetya H (2020). Associations between Physical Activity, Depression, and Quality of Life in Elderly: Meta-Analysis. J Epidemiol Public Healt. 05(04): 420-434. https://doi.org/10.26911/jepublichealth.2020.05.04.04.

cc) (i) (-) Journal of Epidemiology and Public Healthis licensed under a Creative Commons Attribution-NonCommercial-ShareAlike 4.o International License.

\section{BACKGROUND}

In 2015, the world's population aged 60 years and over were 900 million people.
This figure is expected to continue to increase until it reaches 2 billion in 2050 (WHO, 2018). The prevalence of age- 
related health problems is a major problem because the proportion of elderly people has increased sharply. The literature shows that elderly people are significantly at risk for various problems affecting organs, such as cardiovascular, respiratory, and memory problems. Growing evidence also suggests that depression, physical inactivity and cognitive impairment are common in the elderly (Yuenyongchaiwat et al, 2018).

A longer lifespan brings opportunities, not only for parents and their families, but also for society as a whole. They are given the opportunity to pursue new activities such as further education, new careers, or pursue interests that have long been neglected. The elderly also contribute in many ways to their families and communities. However, the extent to which these opportunities and contributions really depend on one factor, namely health (WHO, 2018). One of the factors that can increase the life expectancy of the population is to improve the quality of life (da Silva et al, 2018).

The aging process is associated with a greater prevalence of long-term health problems. One of them is a significant increase in problems including mental health problems in the elderly demographic (Miller et al, 2019). The World Health Organization (WHO) estimates that about one in ten elderly people suffer from depression (WHO, 2015).

Depression is one of the most common mental health problems in the elderly. It is estimated that $10-15 \%$ of elderly aged 65 years old and over who live in the community experience symptoms of depression at some point (Miller et al, 2019). Mental disorders such as depression are often associated with increased psychological stress in the elderly.

Depressive symptoms in the elderly are triggered by several factors such as the use of various types of drugs and the influence of other psychiatric disorders; such as obsessive-compulsive disorder or panic disorder (Oliviera et al, 2019). Symptoms of depression can include persistent sadness; irritable or anxious mood; reduced concentration and attention; low energy levels or fatigue; low self-confidence; feeling hopeless; trouble sleeping or appetite; loss of interest or pleasure in activities that were once enjoyable; or difficulties in doing casual work or social activities (American Psychiatric Association, 2013). In the elderly, depression is also associated with decreased cognitive abilities which is usually accompanied by decreased social and physical activity (Teixeira et al, 2013). Depression can lead to delays in therapeutic response and worsens the prognosis of patients with anxiety disorders. Furthermore, depression also triggers suicide attempts in geriatric patients. All of these factors will reduce the quality of life (QOL) of the elderly (Oliviera et al, 2019).

QOL can be conceptualized as a set of harmonious satisfactions that individuals get in their daily lives by considering physical, psychological and social aspects of life (Sampaio et al, 2013). Good QOL for the elderly can be interpreted as feeling better in carrying out basic daily activities (Activity of Daily Living/ADLs) properly and living independently (Bhamani et al, 2015). Therefore, QOL is the target of a program aimed at helping the elderly to live independently and enjoy their old age happily (Oliviera et al, 2019). One of the aspects that play an important role in improving the quality of life of the elderly is physical activity.

\section{SUBJECTS AND METHOD}

\section{Study Design}

This was a systematic review and meta-analysis study. The articles used in this study 
Prabandari et al./ Physical Activity, Depression, and Quality of Life in Elderly

were obtained from several databases including PubMed, Google Scholar, Springerlink, and Sciencedirect. The keywords for finding articles are as follows: "physical activity", "depression", "quality of life", "elderly", "cross-sectional" and "adjusted odds ratio".

\section{Inclusion Criteria}

The articles included in this study are fulltext articles with a cross-sectional study design and in English. The appropriate article should mention the elderly population, physical activity interventions with depression and quality of life outcomes. Articles must be published in 2010-2020 with the multivariate adjusted Odds Ratio.

\section{Criteria Exclusion}

The articles published in this study are articles that have been conducted in a previous meta-analysis and used subjects aged $<60$ years old.

\section{Operational Definition of Variables}

The article search was carried out by considering the eligibility criteria defined using the PICO model. The population in the study were men and women aged $\geq 60$ years old with interventions in the form of physical activity.

Comparison is sedentary behavior and outcome in the form of depression and quality of life.

Physical activity is a body movement that requires energy expenditure

Depression is a mental health problem with a variety of symptoms that can affect a person's life

Quality of life is self-satisfaction with the life that is lived.

\section{Data Analysis}

Data processing was carried out by the Review Manager (RevMan 5.3) by calculating the adjusted Odds Ratio (aOR) and heterogeneity to determine the study merger model and form the final meta-analysis result.

\section{RESULTS}

The process of searching for articles was done by searching through a database. The article obtained can be seen in Figure 1.

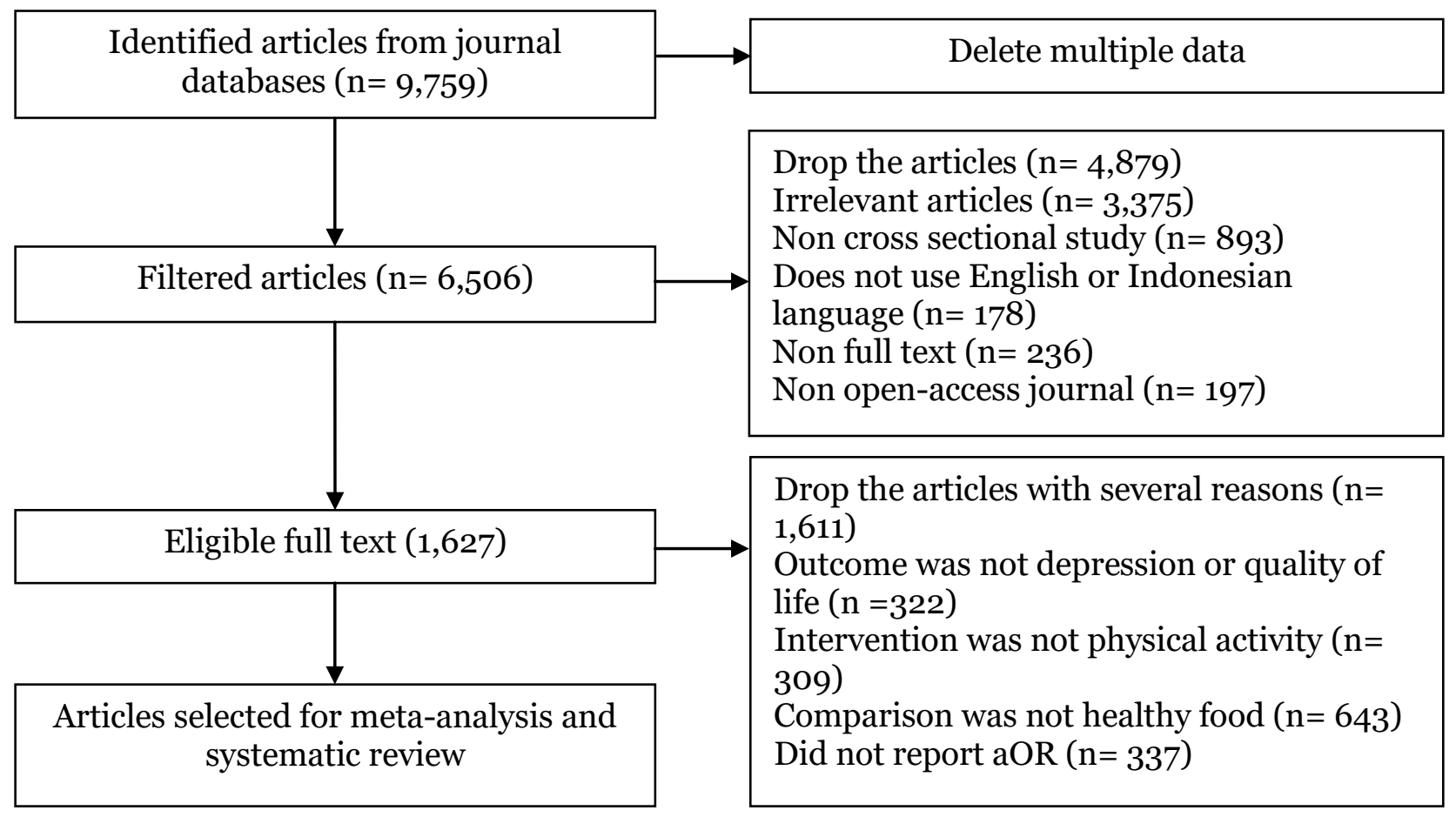

Figure 1. PRISMA flow diagram 
1. The relationship between physical activity and depression in the elderly

a. Summary of Source Articles

Table 1. Primary study descriptions included in the meta-analysis

\begin{tabular}{|c|c|c|c|c|c|c|c|c|}
\hline $\begin{array}{c}\text { Author } \\
\text { (year) }\end{array}$ & Title & Country & $\begin{array}{c}\text { Study } \\
\text { Design }\end{array}$ & Sample & $\begin{array}{c}\mathbf{P} \\
\text { Population } \\
\end{array}$ & $\begin{array}{c}\text { I } \\
\text { Intervention } \\
\end{array}$ & $\begin{array}{c}\mathrm{C} \\
\text { Comparison }\end{array}$ & $\begin{array}{c}\text { O } \\
\text { Outcome }\end{array}$ \\
\hline $\begin{array}{l}\text { Gupta et al. } \\
(2020)\end{array}$ & $\begin{array}{l}\text { Predictors of depress- } \\
\text { ion and dementia } \\
\text { among elderly people in } \\
\text { rural Jodhpur }\end{array}$ & India & $\begin{array}{l}\text { Cross- } \\
\text { sectional }\end{array}$ & 152 & $\begin{array}{l}\text { Subjects aged } \\
60 \text { years old } \\
\text { and over }\end{array}$ & $\begin{array}{l}\text { Physical activity } \\
\text { (daily activities) }\end{array}$ & $\begin{array}{l}\text { Sedentary } \\
\text { behavior }\end{array}$ & Depression \\
\hline Byeon (2019) & $\begin{array}{l}\text { Relationship between } \\
\text { physical activity level } \\
\text { and depression of } \\
\text { elderly people living } \\
\text { alone: Results from a } \\
\text { Nationally Represen- } \\
\text { tative Sample of Elderly } \\
\text { in South Korea }\end{array}$ & $\begin{array}{l}\text { South } \\
\text { Korea }\end{array}$ & $\begin{array}{l}\text { Cross- } \\
\text { sectional }\end{array}$ & 256 & $\begin{array}{l}\text { Subjects aged } \\
62 \text { to } 93 \\
\text { years old }\end{array}$ & $\begin{array}{l}\text { Physical activity } \\
\text { (sitting position, } \\
\text { aerobics, walking, } \\
\text { flexibility training, } \\
\text { muscle } \\
\text { strengthening } \\
\text { exercises) }\end{array}$ & $\begin{array}{l}\text { Sedentary } \\
\text { behavior }\end{array}$ & Depression \\
\hline $\begin{array}{l}\text { de Oliveira et } \\
\text { al. Piva } \\
\text { (2019) }\end{array}$ & $\begin{array}{l}\text { The effects of physical } \\
\text { activity on anxiety, } \\
\text { depression, and quality } \\
\text { of life in elderly people } \\
\text { living in the community }\end{array}$ & Brazil & $\begin{array}{l}\text { Cross- } \\
\text { sectional }\end{array}$ & 200 & $\begin{array}{l}\text { Subjects aged } \\
65 \text { to } 79 \text { years } \\
\text { old }\end{array}$ & Physical activity & $\begin{array}{l}\text { Sedentary } \\
\text { behavior }\end{array}$ & Depression \\
\hline $\begin{array}{l}\text { Disu et al. } \\
(2019)\end{array}$ & $\begin{array}{l}\text { Risk factors of geriatric } \\
\text { depression among } \\
\text { elderly Bangladeshi } \\
\text { people: A pilot inter- } \\
\text { view study }\end{array}$ & Bangladesh & $\begin{array}{l}\text { Cross- } \\
\text { sectional }\end{array}$ & 168 & $\begin{array}{l}\text { Subjects aged } \\
60 \text { to } 80 \\
\text { years old }\end{array}$ & $\begin{array}{l}\text { Physical activity } \\
\text { (daily activity, } \\
\text { regular exercise) }\end{array}$ & $\begin{array}{l}\text { Sedentary } \\
\text { behavior }\end{array}$ & Depression \\
\hline $\begin{array}{l}\text { Yasunaga et } \\
\text { al. (2018) }\end{array}$ & $\begin{array}{l}\text { Cross-sectional asso- } \\
\text { ciations of sedentary } \\
\text { behaviour and physical } \\
\text { activity on depression } \\
\text { in Japanese older } \\
\text { adults: an isotemporal } \\
\text { substitution approach }\end{array}$ & Japan & $\begin{array}{l}\text { Cross- } \\
\text { sectional }\end{array}$ & 276 & $\begin{array}{l}\text { Subjects aged } \\
65 \text { to } 85 \\
\text { years old }\end{array}$ & $\begin{array}{l}\text { Physical activity } \\
\text { (Light-intensity } \\
\text { physical activity, } \\
\text { Moderate-to- } \\
\text { Vigorous physical } \\
\text { activity) }\end{array}$ & $\begin{array}{l}\text { Sedentary } \\
\text { behavior }\end{array}$ & Depression \\
\hline
\end{tabular}


Prabandari et al./ Physical Activity, Depression, and Quality of Life in Elderly

\begin{tabular}{|c|c|c|c|c|c|c|c|c|}
\hline $\begin{array}{l}\text { Oh et al. } \\
\text { (2017) }\end{array}$ & $\begin{array}{l}\text { Association between } \\
\text { exercise type and qua- } \\
\text { lity of life in a commu- } \\
\text { nity-dwelling older } \\
\text { people: A cross- } \\
\text { sectional study }\end{array}$ & Korea & $\begin{array}{c}\text { Cross- } \\
\text { sectional }\end{array}$ & 1586 & $\begin{array}{l}\text { Subjects aged } \\
65 \text { years old } \\
\text { and over }\end{array}$ & $\begin{array}{l}\text { Physical activity } \\
\text { (Resistance, } \\
\text { Flexibility, } \\
\text { Walking) }\end{array}$ & $\begin{array}{l}\text { Sedentary } \\
\text { behavior }\end{array}$ & Depression \\
\hline $\begin{array}{l}\text { Behera et al. } \\
\text { (2016) }\end{array}$ & $\begin{array}{l}\text { Prevalence and deter- } \\
\text { minants of depression } \\
\text { among elderly persons } \\
\text { in a rural community } \\
\text { from northern India }\end{array}$ & North India & $\begin{array}{l}\text { Cross- } \\
\text { sectional }\end{array}$ & 395 & $\begin{array}{l}\text { Subjects aged } \\
\text { 6oyears old } \\
\text { and over }\end{array}$ & $\begin{array}{l}\text { Physical activity } \\
\text { (walking, } \\
\text { household work, } \\
\text { farm work, } \\
\text { combination) }\end{array}$ & $\begin{array}{l}\text { Sedentary } \\
\text { behavior }\end{array}$ & Depression \\
\hline $\begin{array}{l}\text { Park et al. } \\
(2015)\end{array}$ & $\begin{array}{l}\text { Above-moderate phy- } \\
\text { sical activity reduces } \\
\text { both incident and per- } \\
\text { sistent late-life depress- } \\
\text { ion in rural Koreans }\end{array}$ & Korea & $\begin{array}{l}\text { Cross- } \\
\text { sectional }\end{array}$ & 701 & $\begin{array}{l}\text { Subjects aged } \\
65 \text { years old } \\
\text { and over }\end{array}$ & $\begin{array}{l}\text { Physical activity } \\
\text { (mild, above- } \\
\text { moderate) }\end{array}$ & $\begin{array}{l}\text { Sedentary } \\
\text { behavior }\end{array}$ & Depression \\
\hline $\begin{array}{l}\text { Wassink- } \\
\text { Vossen et al. } \\
\text { (2014) }\end{array}$ & $\begin{array}{l}\text { Physical (in)activity } \\
\text { and depression in older } \\
\text { people }\end{array}$ & Netherlands & $\begin{array}{l}\text { Cross- } \\
\text { sectional }\end{array}$ & 378 & $\begin{array}{l}\text { Subjects aged } \\
\text { 6oyears old } \\
\text { and over }\end{array}$ & Physical activity & $\begin{array}{l}\text { Sedentary } \\
\text { behavior }\end{array}$ & Depression \\
\hline $\begin{array}{l}\text { Chen et al. } \\
\text { (2012) }\end{array}$ & $\begin{array}{l}\text { Relationships of } \\
\text { leisure-time and non- } \\
\text { leisure-time physical } \\
\text { activity with depressive } \\
\text { symptoms: a popu- } \\
\text { lation-based study of } \\
\text { Taiwanese older adults }\end{array}$ & Taiwan & $\begin{array}{l}\text { Cross- } \\
\text { sectional }\end{array}$ & 2727 & $\begin{array}{l}\text { Subjects aged } \\
65 \text { years old } \\
\text { and over }\end{array}$ & $\begin{array}{l}\text { Physical activity } \\
\text { (Leisure-time } \\
\text { physical activity, } \\
\text { Non leisure-time } \\
\text { physical activity) }\end{array}$ & $\begin{array}{l}\text { Sedentary } \\
\text { behavior }\end{array}$ & Depression \\
\hline
\end{tabular}


Prabandari et al./ Physical Activity, Depression, and Quality of Life in Elderly

\section{b. Forest Plot}

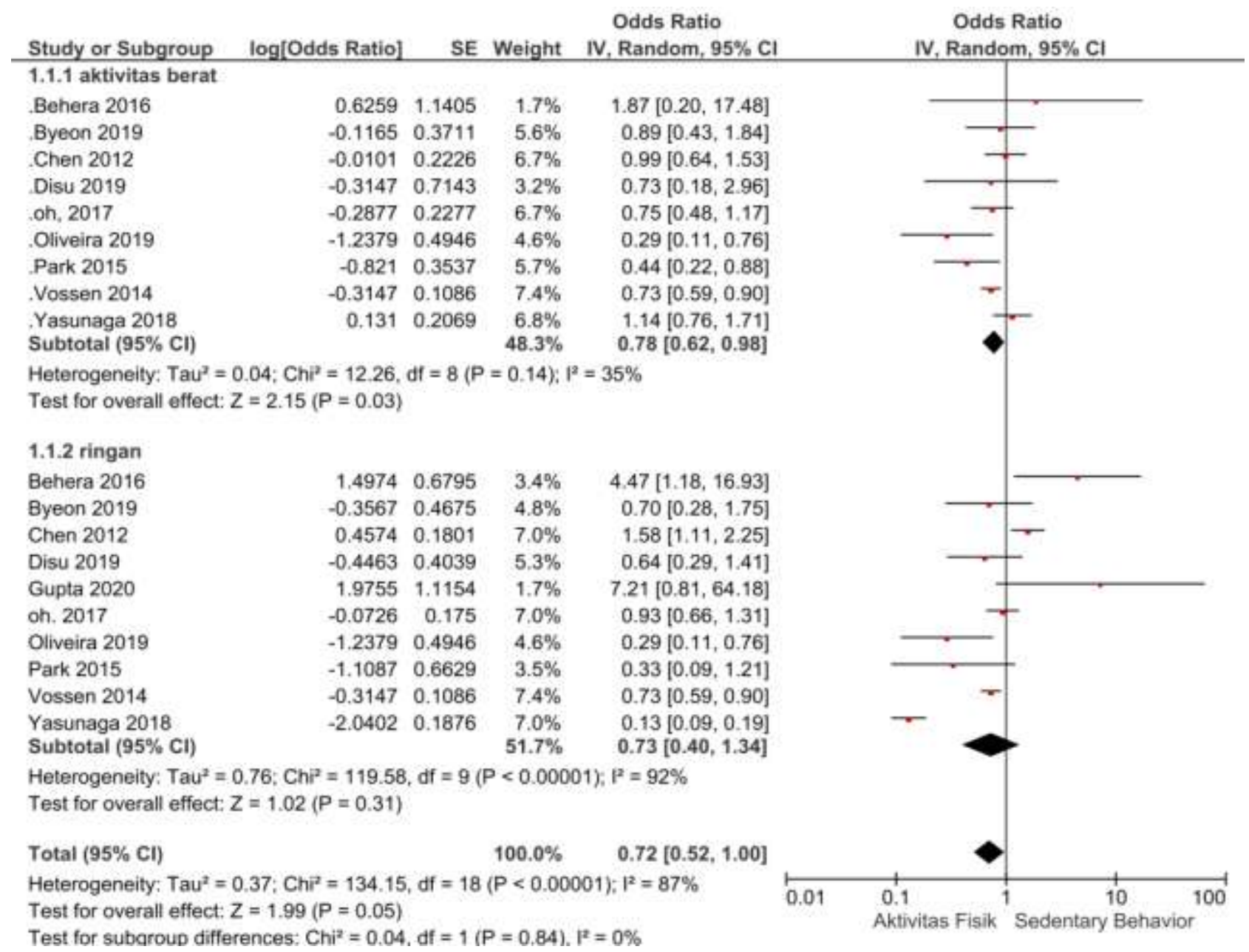

\section{Figure 3. Forest Plot of the relationship between physical activity and depression in the elderly}

Based on the results of the forest plot (Figure 3), physical activity can reduce the risk of depression by 0.72 times higher compared to sedentary behavior and it is statistically significant ( $\mathrm{p}<0.001)$. The heterogeneity of the study data showed $\mathrm{I}^{2}=$ $87 \%$ so that the distribution of the data was stated as heterogeneous (random effect model). 
Prabandari et al./ Physical Activity, Depression, and Quality of Life in Elderly

c. Funnel Plot

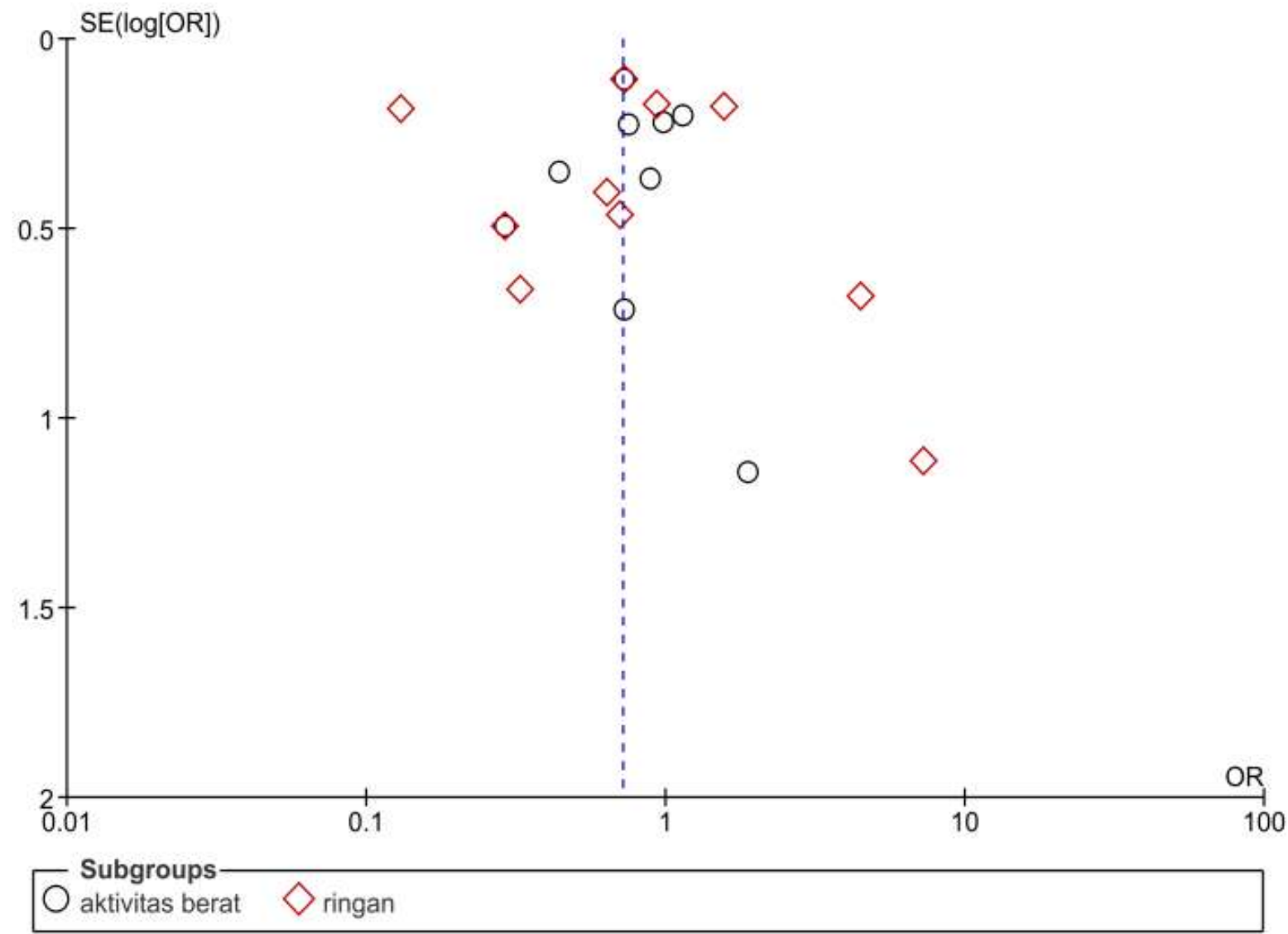

Figure 4. Funnel Plot of the relationship between physical activity and depression in the elderly

The funnel plot (figure 4) shows a publication bias which is characterized by asymmetry of the right and left plots where 9 plots are on the right, 5 plots are on the left, and 3 plots are in the middle. The plot on the right of the graph appears to have a standard error (SE) between 0.2 and 0.7 . The plot on the left of the graph appears to have a standard error (SE) between $O$ and 1.1. 
2. The relationship between physical activity and quality of life

a. Summary Source Article

Table 2. Primary study descriptions included in the meta-analysis

\begin{tabular}{|c|c|c|c|c|c|c|c|c|}
\hline $\begin{array}{c}\text { Author } \\
\text { (year) }\end{array}$ & Title & Country & $\begin{array}{c}\text { Study } \\
\text { Design } \\
\end{array}$ & Sample & $\begin{array}{c}\text { P } \\
\text { Population }\end{array}$ & $\begin{array}{c}\text { I } \\
\text { Intervention }\end{array}$ & $\begin{array}{c}\text { C } \\
\text { Comparison }\end{array}$ & $\begin{array}{c}\text { O } \\
\text { Outcome }\end{array}$ \\
\hline $\begin{array}{l}\text { Yadav et al. } \\
(2020)\end{array}$ & $\begin{array}{l}\text { Biosocial and disease conditions } \\
\text { are associated with good quality } \\
\text { of life among older adults in } \\
\text { rural eastern Nepal: Findings } \\
\text { from a cross- sectional study }\end{array}$ & Nepal & $\begin{array}{l}\text { Cross- } \\
\text { sectional }\end{array}$ & 794 & $\begin{array}{l}\text { Subject aged } \\
60 \text { years old } \\
\text { and over }\end{array}$ & $\begin{array}{l}\text { Physical } \\
\text { Activity }\end{array}$ & $\begin{array}{l}\text { Sedentary } \\
\text { behavior }\end{array}$ & $\begin{array}{l}\text { Quality of } \\
\text { Life }\end{array}$ \\
\hline $\begin{array}{l}\text { de Oliveira } \\
\text { et al. (2019) }\end{array}$ & $\begin{array}{l}\text { The effects of hysical activity on } \\
\text { anxiety, depression, and quality } \\
\text { of life in elderly people living in } \\
\text { the community }\end{array}$ & Brazil & $\begin{array}{l}\text { Cross- } \\
\text { sectional }\end{array}$ & 200 & $\begin{array}{l}\text { Subject aged } \\
65 \text { to } 79 \text { years } \\
\text { old }\end{array}$ & $\begin{array}{l}\text { Physical } \\
\text { Activity }\end{array}$ & $\begin{array}{l}\text { Sedentary } \\
\text { behavior }\end{array}$ & $\begin{array}{l}\text { Quality of } \\
\text { Life }\end{array}$ \\
\hline $\begin{array}{l}\text { Damayanthi } \\
\text { et al. (2018) }\end{array}$ & $\begin{array}{l}\text { Health related quality of life and } \\
\text { its associated factors among } \\
\text { community dwelling older } \\
\text { people in Sri Lanka: A cross- } \\
\text { sectional study }\end{array}$ & Sri Lanka & $\begin{array}{l}\text { Cross- } \\
\text { sectional }\end{array}$ & 1300 & $\begin{array}{l}\text { Subject aged } \\
60 \text { years old } \\
\text { and over }\end{array}$ & $\begin{array}{l}\text { Physical } \\
\text { Activity }\end{array}$ & $\begin{array}{l}\text { Sedentary } \\
\text { behavior }\end{array}$ & $\begin{array}{l}\text { Quality of } \\
\text { Life }\end{array}$ \\
\hline $\begin{array}{l}\text { Oh et al. } \\
(2017)\end{array}$ & $\begin{array}{l}\text { Association between exercise } \\
\text { type and quality of life in a } \\
\text { community-dwelling older } \\
\text { people: A cross-sectional study }\end{array}$ & Korea & $\begin{array}{l}\text { Cross- } \\
\text { sectional }\end{array}$ & 1586 & $\begin{array}{l}\text { Subject aged } \\
65 \text { years old } \\
\text { and over }\end{array}$ & $\begin{array}{l}\text { Physical acti- } \\
\text { vity (resist- } \\
\text { ance, flexibi- } \\
\text { lity, walking) }\end{array}$ & $\begin{array}{l}\text { Sedentary } \\
\text { behavior }\end{array}$ & $\begin{array}{l}\text { Quality of } \\
\text { Life }\end{array}$ \\
\hline $\begin{array}{l}\text { Miranda et } \\
\text { al. } \\
(2016)\end{array}$ & $\begin{array}{l}\text { Quality of life and associated } \\
\text { factors in elderly people at a } \\
\text { Reference Center }\end{array}$ & Brazil & $\begin{array}{l}\text { Cross- } \\
\text { sectional }\end{array}$ & 257 & $\begin{array}{l}\text { Subject aged } \\
60 \text { years old } \\
\text { and over }\end{array}$ & $\begin{array}{l}\text { Physical acti- } \\
\text { vity (physical } \\
\text { exercise) }\end{array}$ & $\begin{array}{l}\text { Sedentary } \\
\text { behavior }\end{array}$ & $\begin{array}{l}\text { Quality of } \\
\text { Life }\end{array}$ \\
\hline $\begin{array}{l}\text { Li et al. } \\
(2014)\end{array}$ & $\begin{array}{l}\text { Successful aging defined by } \\
\text { health-related quality of life and } \\
\text { its determinants in } \\
\text { communitydwelling elders }\end{array}$ & Taiwan & $\begin{array}{l}\text { Cross- } \\
\text { sectional }\end{array}$ & 903 & $\begin{array}{l}\text { Subject aged } \\
65 \text { years old } \\
\text { and over }\end{array}$ & $\begin{array}{l}\text { Physical acti- } \\
\text { vity (physical } \\
\text { exercise) }\end{array}$ & $\begin{array}{l}\text { Sedentary } \\
\text { behavior }\end{array}$ & $\begin{array}{l}\text { Quality of } \\
\text { Life }\end{array}$ \\
\hline $\begin{array}{l}\text { Brown et al. } \\
(2014)\end{array}$ & $\begin{array}{l}\text { Physical activity and health- } \\
\text { related quality of life: US adults } \\
\text { with and without limitations }\end{array}$ & US & $\begin{array}{l}\text { Cross- } \\
\text { sectional }\end{array}$ & 69,127 & $\begin{array}{l}\text { Subject aged } \\
65 \text { years old } \\
\text { and over }\end{array}$ & $\begin{array}{l}\text { Physical } \\
\text { activity }\end{array}$ & $\begin{array}{l}\text { Sedentary } \\
\text { behavior }\end{array}$ & $\begin{array}{l}\text { Quality of } \\
\text { Life }\end{array}$ \\
\hline
\end{tabular}


Prabandari et al./ Physical Activity, Depression, and Quality of Life in Elderly

\begin{tabular}{|c|c|c|c|c|c|c|c|c|}
\hline Cho (2014) & $\begin{array}{l}\text { The positive effect of physical } \\
\text { activity on health and } \\
\text { health-related quality of life in } \\
\text { elderly Korean people-evidence } \\
\text { from the fifth Korea National } \\
\text { Health and } \\
\text { Nutrition Examination Survey }\end{array}$ & Korea & $\begin{array}{l}\text { Cross- } \\
\text { sectional }\end{array}$ & 2853 & $\begin{array}{l}\text { Subject aged } \\
\text { 65years old } \\
\text { and over }\end{array}$ & $\begin{array}{l}\text { Physical acti- } \\
\text { vity (low, } \\
\text { moderate, } \\
\text { virgous phy- } \\
\text { sical activity) }\end{array}$ & $\begin{array}{l}\text { Sedentary } \\
\text { behavior }\end{array}$ & $\begin{array}{l}\text { Quality of } \\
\text { Life }\end{array}$ \\
\hline
\end{tabular}


Prabandari et al./ Physical Activity, Depression, and Quality of Life in Elderly

b. Forest Plot

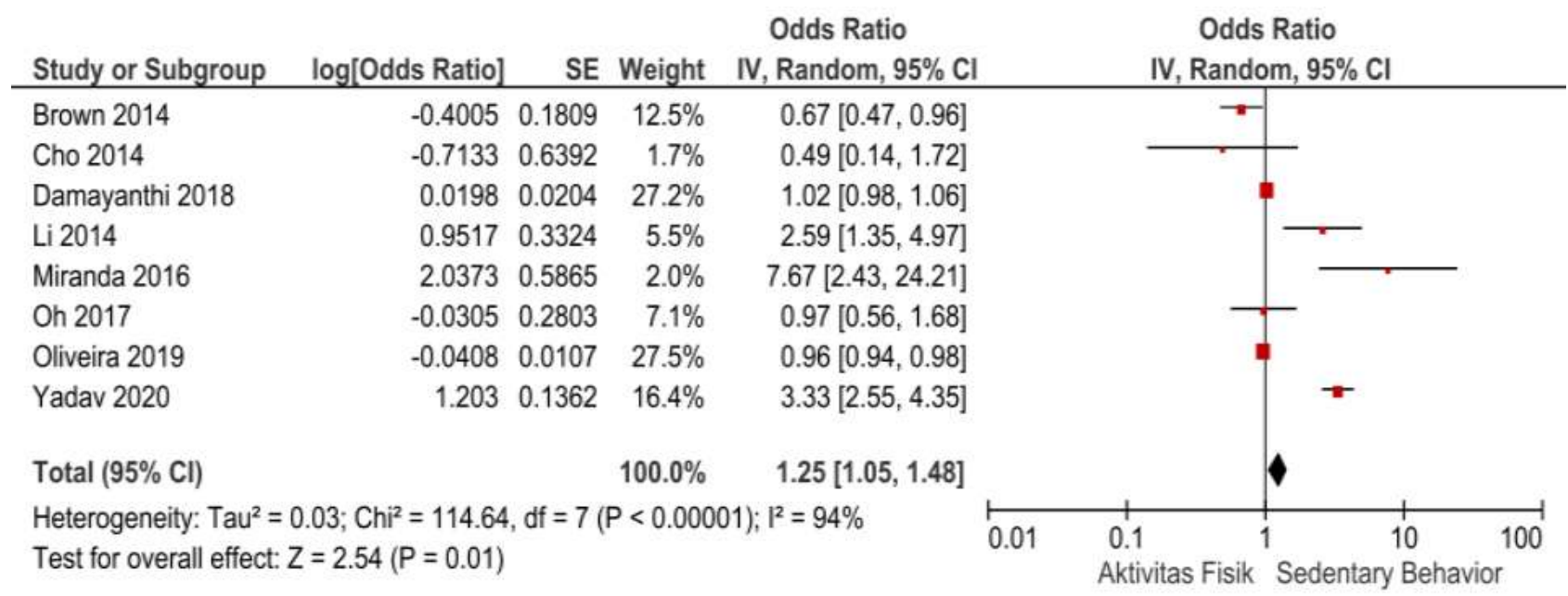

Figure 5. Forest plot of the relationship between physical activity and quality of life of the elderly

Forest plot. (Figure 5) shows that physical activity can improve the quality of life of the elderly by 1.25 times higher compared to sedentary behavior and it is statistically significant $(p<0.001)$. The heterogeneity of the research data shows $\mathrm{I}^{2}=94 \%$ so that the distribution of the data is heterogeneous (random effect model).

\section{c. Funnel Plot}

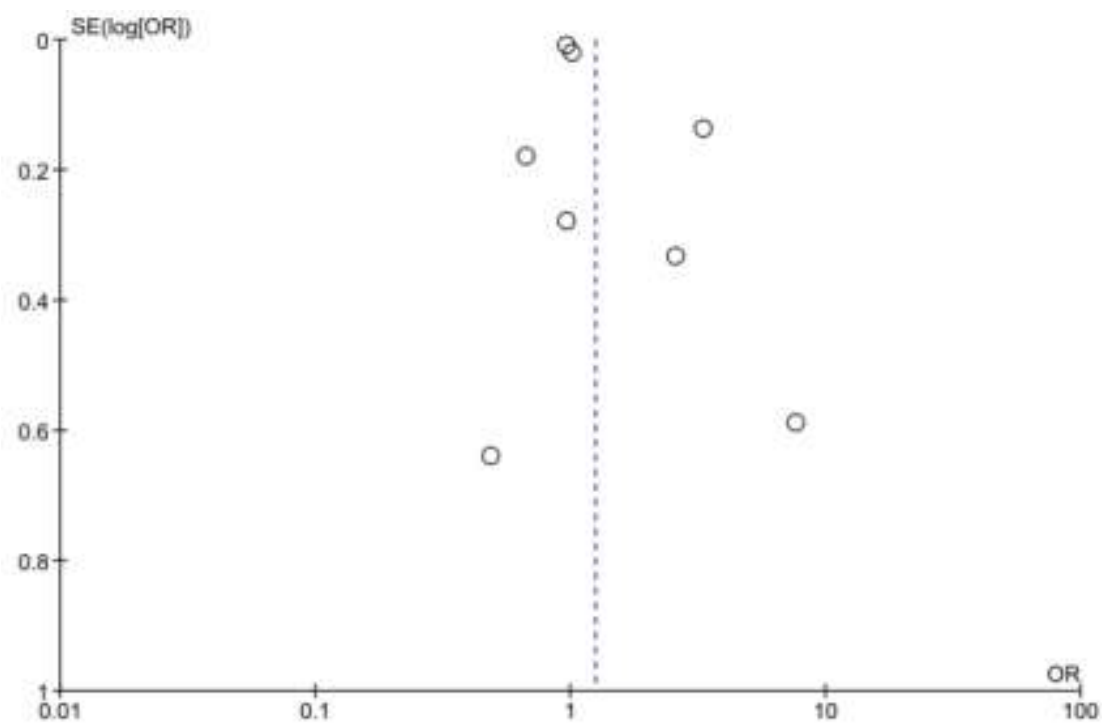

Figure 6. Funnel plot of the relationship between physical activity and quality of life of the elderly

Figure 6 shows that there is a publication bias which is indicated by asymmetry of the right and left plots, with 3 plots on the right and 5 plots on the left. The plot on the right of the graph appears to have a standard error (SE) between 0.15 and o.6. The plot on the left of the graph appears to have a standard error (SE) between $o$ and 0.65 . 
Table 3. Critical Appraisal Checklist for Cross-sectional Study

\begin{tabular}{|c|c|c|c|c|c|c|c|c|c|c|}
\hline Checklist Questions & $\begin{array}{l}\text { Gupta, } \\
\text { et al. } \\
(\mathbf{2 0 2 0})\end{array}$ & $\begin{array}{l}\text { Byeon } \\
(\mathbf{2 0 1 9})\end{array}$ & $\begin{array}{l}\text { Oliveira } \\
\text { et al. } \\
\text { (2019) }\end{array}$ & $\begin{array}{l}\text { Disu } \\
\text { et al. } \\
\text { (2019) }\end{array}$ & $\begin{array}{l}\text { Yasunaga } \\
\text { et al. } \\
\text { (2018) }\end{array}$ & $\begin{array}{c}\text { Oh et } \\
\text { al. } \\
(2018)\end{array}$ & $\begin{array}{l}\text { Behera } \\
\text { et al. } \\
(2016)\end{array}$ & $\begin{array}{l}\text { Park } \\
\text { et al. } \\
\text { (2015) }\end{array}$ & $\begin{array}{l}\text { Vossen } \\
\text { et al. } \\
(2014)\end{array}$ & $\begin{array}{l}\text { Chen } \\
\text { et al. } \\
(2012)\end{array}$ \\
\hline $\begin{array}{l}\text { Does this objective clearly address } \\
\text { the focus/study problem? }\end{array}$ & 1 & 1 & 1 & 1 & 1 & 1 & 1 & 1 & 1 & 1 \\
\hline $\begin{array}{l}\text { Is the study method (study } \\
\text { design) appropriate for answering } \\
\text { study questions? }\end{array}$ & 1 & 1 & 1 & 1 & 1 & 1 & 1 & 1 & 1 & 1 \\
\hline $\begin{array}{l}\text { Is the method of selecting study } \\
\text { subjects clearly written? }\end{array}$ & 1 & 1 & 1 & 1 & 1 & 1 & 1 & 1 & 1 & 1 \\
\hline $\begin{array}{l}\text { Can the sampling method } \\
\text { introduce bias (selection)? }\end{array}$ & $\mathrm{o}$ & o & $\mathrm{o}$ & o & $\mathrm{o}$ & o & o & o & o & o \\
\hline $\begin{array}{l}\text { Does the study sample taken } \\
\text { represent the designated } \\
\text { population? }\end{array}$ & 1 & 1 & 1 & 1 & 1 & 1 & 1 & 1 & 1 & 1 \\
\hline $\begin{array}{l}\text { Is the sample size based on pre- } \\
\text { study considerations? }\end{array}$ & o & $\mathrm{O}$ & $\mathrm{O}$ & o & $\mathrm{O}$ & $\mathrm{O}$ & $\mathrm{O}$ & $\mathrm{O}$ & o & o \\
\hline $\begin{array}{l}\text { Is a satisfactory response } \\
\text { achieved? }\end{array}$ & 1 & 1 & 1 & 1 & 1 & 1 & 1 & 1 & 1 & 1 \\
\hline $\begin{array}{l}\text { Are the study instruments valid } \\
\text { and reliable? }\end{array}$ & 1 & 1 & 1 & 1 & 1 & 1 & 1 & 1 & 1 & 1 \\
\hline $\begin{array}{l}\text { Is statistical significance } \\
\text { assessed? }\end{array}$ & 1 & 1 & 1 & 1 & 1 & 1 & 1 & 1 & 1 & 1 \\
\hline $\begin{array}{l}\text { Are confidence intervals given for } \\
\text { the main outcome? }\end{array}$ & 1 & 1 & 1 & 1 & 1 & 1 & 1 & 1 & 1 & 1 \\
\hline $\begin{array}{l}\text { Are there any confounding factors } \\
\text { that have not been taken into } \\
\text { account? }\end{array}$ & O & O & O & O & O & O & O & $\mathrm{O}$ & O & O \\
\hline $\begin{array}{l}\text { Are the results applicable to your } \\
\text { study? }\end{array}$ & 1 & 1 & 1 & 1 & 1 & 1 & 1 & 1 & 1 & 1 \\
\hline Total & 9 & 9 & 9 & 9 & 9 & 9 & 9 & 9 & 9 & 9 \\
\hline
\end{tabular}

Answer: $1=$ Yes, $\mathbf{O}=$ No 
Table 4. Critical Appraisal Checklist for Cross sectional Study

\begin{tabular}{|c|c|c|c|c|c|c|c|c|}
\hline Checklist Questions & $\begin{array}{l}\text { Yadav } \\
\text { et al. } \\
(2020)\end{array}$ & $\begin{array}{c}\text { Oliveira } \\
\text { et al. } \\
\text { (2019) }\end{array}$ & $\begin{array}{l}\text { Damayanthi } \\
\text { et al. (2018) }\end{array}$ & $\begin{array}{c}\text { Oh et } \\
\text { al. } \\
(2017)\end{array}$ & $\begin{array}{c}\text { Miranda } \\
\text { et al. } \\
\text { (2016) }\end{array}$ & $\begin{array}{c}\text { Li et } \\
\text { al. } \\
(2014)\end{array}$ & $\begin{array}{c}\text { Brown } \\
\text { et al. } \\
\text { (2014) }\end{array}$ & $\begin{array}{l}\text { Cho et } \\
\text { al. } \\
(2014)\end{array}$ \\
\hline $\begin{array}{l}\text { Does this objective clearly address the } \\
\text { focus/study problem? }\end{array}$ & 1 & 1 & 1 & 1 & 1 & 1 & 1 & 1 \\
\hline $\begin{array}{l}\text { Is the study method (study design) appropriate } \\
\text { for answering study questions? }\end{array}$ & 1 & 1 & 1 & 1 & 1 & 1 & 1 & 1 \\
\hline $\begin{array}{l}\text { Is the method of selecting study subjects clearly } \\
\text { written? }\end{array}$ & 1 & 1 & 1 & 1 & 1 & 1 & 1 & 1 \\
\hline $\begin{array}{l}\text { Can the sampling method introduce bias } \\
\text { (selection)? }\end{array}$ & o & $\mathrm{o}$ & $\mathrm{o}$ & $\mathrm{O}$ & o & $\mathrm{O}$ & o & o \\
\hline $\begin{array}{l}\text { Does the study sample taken represent the } \\
\text { designated population? }\end{array}$ & 1 & 1 & 1 & 1 & 1 & 1 & 1 & 1 \\
\hline $\begin{array}{l}\text { Is the sample size based on pre-study } \\
\text { considerations? }\end{array}$ & o & o & $\mathrm{o}$ & $\mathrm{O}$ & $\mathrm{O}$ & $\mathrm{O}$ & $\mathrm{O}$ & o \\
\hline Is a satisfactory response achieved? & 1 & 1 & 1 & 1 & 1 & 1 & 1 & 1 \\
\hline Are the study instruments valid and reliable? & 1 & 1 & 1 & 1 & 1 & 1 & 1 & 1 \\
\hline Is statistical significance assessed? & 1 & 1 & 1 & 1 & 1 & 1 & 1 & 1 \\
\hline $\begin{array}{l}\text { Are confidence intervals given for the main } \\
\text { outcome? }\end{array}$ & 1 & 1 & 1 & 1 & 1 & 1 & 1 & 1 \\
\hline $\begin{array}{l}\text { Are there any confounding factors that have not } \\
\text { been taken into account? }\end{array}$ & o & o & o & o & o & o & o & o \\
\hline Are the results applicable to your study? & 1 & 1 & 1 & 1 & 1 & 1 & 1 & 1 \\
\hline Total & 9 & 9 & 9 & 9 & 9 & 9 & 9 & 9 \\
\hline
\end{tabular}

Answer: $1=$ Yes, $\mathrm{O}=\mathrm{No}$ 


\section{DISCUSSION}

This systematic and meta-analysis study used study that controlled for confounding factors which could be seen from the study inclusion requirements, namely multivariate analysis and the statistical result reported was the adjusted odd ratio (aOR).

Estimated association of physical activity with depression and quality of life of elderly in RevMan 5.3 application. The study results are presented in the form of a forest plot and a funnel plot. The forest plot provides an overview of information from each of the studies investigated in the metaanalysis, and estimates of the overall results (Murti, 2018).

The funnel plot shows the amount of variation visually (heterogeneity) (Akobeng, 2005 in Murti, 2018). The funnel plot shows the relationship between the effect size of the study and the sample size of the various studies under study, which can be measured in a number of different ways. (Murti, 2018).

The relationship between physical activity and depression in the elderly. The results of the forest plot from the study article show that the elderly who do physical activity show that physical activity can reduce the risk of depression by 0.72 times compared to sedentary behavior. This is consistent with the theory that physical activity contributes to reducing psychological stress among the elderly because it encourages psychosocial interactions, increases self-confidence, helps maintain and improve cognitive function, and reduces the frequency of relapses in cases of depression and anxiety (Teixeira et al., 2013).

Oliveira et al. (2019), also reported a statistically significant association between physical activity and anxiety and depression $(\mathrm{aOR}=0.29 ; 95 \% \mathrm{CI}=0.11$ to $0.79 ; \mathrm{p}=$ $<0.05$ ). Physiologically, the aging process does not necessarily coincide with the chronological progress of age. Aging can be influenced by several combined factors, including biological aging, disease incidence, and certain lifestyle patterns, such as low physical activity. In this study, when comparing the results of anxiety and depression symptom measurements, a statistically significant difference was found.

Elderly who continue to do positive physical activity in their spare time and have more social support can result in higher psychological well-being and ultimately reduce depression. Continuous physical activity can positively affect mental health and thus reduce depression because it can strengthen social support such as increasing friendships, exchanging emotional favors, and discussing problems (Byeon, 2019).

Byeon (2019) added that the participation of the elderly in physical activity can increase physical strength and provide a positive mood for the elderly so that they can improve their ability to overcome depression. Physical activity is known to increase the secretion of antidepressant hormones. Central norepinephrine activity can be temporarily altered, decreasing the hypothalamopituitary-adrenocortical axis, and increasing beta-endorphin secretion. Therefore, doing physical activity can maintain a positive mood, and ultimately prevent depression manifested by negative moods. In particular, depression experienced by the elderly is generally chronic rather than acute, and it reduces the quality of life.

\section{The relationship between physical activity and the quality of life in the elderly.}

The results of the forest plot study articles that have been processed with Revman 5.3 show that physical activity can improve the 
quality of life of the elderly by 1.25 times higher compared to sedentary behavior $(\mathrm{aOR}=1.25 ; 95 \% \mathrm{CI}=1.05$ to $1.48 ; \mathrm{p}$ <0.001). This study is in line with the theory which states that diet is a risk factor for obesity.

Damayanthi et al. (2018) reported that physical activity is one of the factors that most influenced the quality of life of the elderly $(\mathrm{aOR}=1.02 ; 95 \% \mathrm{CI}=0.98$ to 1.05; $\mathrm{p}<0.3$ ). This study was supported by Oliveira et al. (2019) which showed a positive relationship between physical activity and improved quality of life. In a social context, physical activity encourages better integration in society. In addition, it increases life satisfaction and reduces solitude.

Cho (2014) also show that better Selfrated Health (SRH) and Health-related Quality of Life (HRQoL) are associated with higher activity in the elderly in Korea. Several studies have confirmed that Selfrated Health and Health-related Quality of Life are valid measures of subjective health status, which are associated with, for example, risk of death, psychological well-being, and overall health. People with good or excellent SRH and high HRQoL scores tended to report higher vitality, more positive attitudes, lower susceptibility to disease, more frequent exercise regularly, and higher levels of education and income than those who reported worse SRH and HRQoL.

Therefore, the association suggests that physical activity can increase physical independence as well as an important mental aspect of quality of life. Physical activity increases physical independence by increasing the capacity and physical health which are essential for the autonomy of an individual. Positive changes in life can lead to improvements in mental health conditions and general quality of life generally (Vagetti, 2014).
This meta-analysis concludes that physical activity can reduce the risk of depression in the elderly $(\mathrm{aOR}=0.72 ; 95 \%$ $\mathrm{CI}=0.52$ to $1.00 ; \mathrm{p}<0.001$ ). This meta-analysis combines 12 primary studies and uses a cross-sectional design from India, Korea, Brazil, Bangladesh, Japan, Taiwan and the Netherlands.

This meta-analysis concludes that physical activity can improve the quality of life of the elderly $(\mathrm{aOR}=1.25 ; 95 \% \mathrm{CI}=1.05$ to 1.48 ; $\mathrm{p}<0.001$ ). This meta-analysis combines 8 primary studies using a crosssectional design from Nepal, Brazil, Sri Lanka, Korea, Taiwan, and the US.

\section{AUTHOR CONTRIBUTION}

Ines is the main researcher who selected the topic, explored and collected study data. Bhisma and Hanung have roles in analyzing data and reviewing study documents.

\section{CONFLICT OF INTEREST}

There was no conflict of interest.

\section{FUNDING AND SPONSORSHIP}

This study is self-funded.

\section{ACKNOWLEDGEMENT}

We would like to thank PubMed, Google Scholar, and Springer Link databases,

\section{REFERENCE}

American Psychiatric Association (2013). Diagnostic and statistical manual of mental disorders 540 (5th ed.). Washington, DC: Author.

Bhamani MA, Khan MM, Karim MS, Mir MU (2015). Depression and its association with functional status and physical activity in the elderly in Karachi, Pakistan. Asian J Psychiatr. 14:46-51. https://doi.org/10.1016/j.ajp.2014.12.004. 
Byeon H (2019). Relationship between physical activity level and depression of elderly people living alone: Results from a nationally representative sample of elderly in South Korea. Int J Environ Res Public Health. 16(20): 4051. https://doi.org/10.3390/ijerph16204051.

Cho KO (2014). The positive effect of physical activity on health and healthrelated quality of life in elderly korean people-evidence from the Fifth Korea National Health and Nutrition Examination Survey. J Lifestyle Med. 4(2): 86-94. https://doi.org/10.1528$\mathrm{o} / \mathrm{j} \operatorname{lm} .2014 \cdot 4 \cdot 2.86$.

Damayanthi HDWT, Moy FM, Abdullah KL, Dharmaratne SD (2018). Health related quality of life and its associated factors among community dwelling older people in Sri Lanka: A cross-sectional study. Arch Gerontol Geriat. 76(2018): 215-220. https://doi.org/10.1016/j.archger.2018.03.00 9.

Da Silva MR, Ferreti F, Pinto SS, Filho OFT (2018). Depressive symptoms in the elderly and its relationship with chronic pain, chronic diseases, sleep quality and physical activity level. Br J Pain São Paulo. 1(4):293-298. http://dx.doi.org/10.5935/2595-0118.20180056.

Miller KJ, Mesagno C, McLaren S, Grace F, Yates M, Gomez R (2019). Exercise, mood, self-efficacy, and social support as predictors of depressive symptoms in older adults: Direct and interaction effects. Front Psychol. 10: 2145. https://dx.doi.org/10.3389\%2Ffpsyg. 2019.02145.

Murti B (2018). Prinsip dan Metode Riset Epidemiologi (Epidemiological Rese- arch Principles and Methods). Edisi IV. Cetakan I. Program Studi Ilmu Kesehatan Masyarakat, Program Pascasarjana, Universitas Sebelas Maret. Surakarta.

Oliveira LSSCB, Souya CE, Rodrigues RAS, Fet CA, Piva AB (2019). The effects of physical activity on anxiety, depression, and quality of life in elderly people living in the community. Trends Psychiatry Psychother. 41 (1):1-7. https://doi.org/10.1590/2237-60892017-0129.

Sampaio PYS, Ito E (2013). Activities with higher influence on quality of life in older adults in Japan. Occup Ther Int. 20(1): 1-10. https://doi.org/10.1002/oti.1333.

Teixeira CM, Vasconcelos-Raposo J, Helder MF, Brustad RJ (2013). Physical activity, depression and anxiety among the elderly. Soc Indic Res. 113: 307318. https://doi.org/10.1007/s11205012-0094-9.

Vagetti CG, Moreira NB, Filho VB, Oliveira $\mathrm{V}$ (2014). Association between physical activity and quality of life in the elderly: A systematic review 20002012. Rev Bras Psiquiatr. 36(1): 7688. https://doi.org/10.1590/1516-4446-2012-0895.

World Health Organization (WHO). 2018. Ageing and Health. Viewed August 21 2020, from http://www.who.int/mediacentre/factsheets/fs404/en/.

Yuenyongchaiwa K, Pongpanit K, Hanmanop S (2018). Physical activity and depression in older adults with and without cognitive impairment. Dement Neuropsychol. 12(1):12-18. https://doi.org/10.1590/1980-57642018dn12-010002. 